OPEN ACCESS

Edited by:

Marie Manceau,

Collège de France, France

Reviewed by:

Pedro Martinez,

University of Barcelona, Spain

Patricia Johnston Moore,

University of Georgia, United States

${ }^{*}$ Correspondence:

Luis M. San-Jose

luismsanjose@gmail.com

Specialty section:

This article was submitted to Evolutionary Developmental Biology,

a section of the journal

Frontiers in Ecology and Evolution

Received: 29 February 2020

Accepted: 05 August 2020

Published: 02 September 2020

Citation:

San-Jose LM and Roulin A (2020)

On the Potential Role of the Neural Crest Cells in Integrating Pigmentation

Into Behavioral and Physiological Syndromes. Front. Ecol. Evol. 8:278.

doi: 10.3389/fevo.2020.00278

\section{On the Potential Role of the Neural Crest Cells in Integrating Pigmentation Into Behavioral and Physiological Syndromes}

\author{
Luis M. San-Jose ${ }^{1 *}$ and Alexandre Roulin ${ }^{2}$ \\ ' Laboratoire Évolution and Diversité Biologique, UMR 5174, CNRS, Université Toulouse III Paul Sabatier, Toulouse, France, \\ ${ }^{2}$ Department of Ecology and Evolution, University of Lausanne, Lausanne, Switzerland
}

Melanin pigments color the integument of vertebrates with shades of rufous, gray, and black. In numerous wild species, melanin-based coloration associates to different behavioral, physiological, and morphological traits, yet the proximate basis of such associations remains largely unknown. The neural crest/domestication syndrome hypothesis (Wilkins et al., 2014) proposes that correlated changes in pigmentary, behavioral, physiological, and morphological traits of domestic species result from deficiencies affecting the number or development of neural crest cells in the embryo. Here, we review to what extent the neural crest cells might also explain the associations observed between melanin-based coloration and distinct traits in wild vertebrate populations. Genes involved in the development of the neural crest explain color differences in some vertebrate species, particularly, in cichlid fishes. Cells that originate from the embryo's neural crest cells play functions that have been previously associated with melanin-based coloration in wild vertebrates and we propose the potential mechanisms through which the association of melanin-based coloration with other traits can be the consequence of having a common origin at the neural crest cells. We encourage considering the influence of the neural crest as a new avenue of research, integrating developmental biology and evolutionary ecology to better understand why and how melanin-based coloration of vertebrates become associated to multiple phenotypic aspects.

Keywords: animal signals, aggressiveness, eco-evo-devo, behavior, melanism, pigmentation, phenotypic integration, trait associations

\section{INTRODUCTION}

Most vertebrates color their integuments with melanin pigments (Roy et al., 2020). When deposited in the skin, feathers, scales or hairs, melanins produce different shades of black, gray, and rufous colors (e.g., Stoddard and Prum, 2011). Coloration based on melanin pigments (hereafter referred to as melanin-based coloration, $\mathrm{MbC}$ ) can play different biological functions such as protecting animals from UV radiation (Brenner and Hearing, 2008; Singaravelan et al., 2008), 
promoting thermal adaptation by regulating heat gain (Clusella-Trullas et al., 2008), and mediating social and mating encounters in the case of melanin-based ornamental signals (Roulin, 2016).

Moreover, studies in wild vertebrate populations have repeatedly shown that the expression of $\mathrm{MbC}$ is associated with multiple aspects of an individual's phenotype including physiology (metabolism, stress response and stress hormone levels), immunology (inflammatory response and parasite load), morphology (body size and mass), behavior (aggressiveness, boldness, and exploratory behavior) and reproductive traits (sex hormone levels and fecundity) (reviewed in San-Jose and Roulin, 2018). Often, these associations have the same sign in different species. For instance, individuals with a darker or more extended MbC (i.e., entailing a higher deposition of melanin pigments, generally eumelanin) have been often found to be more aggressive and/or to have a higher social rank in different vertebrate taxa, including fishes (Schweitzer et al., 2015), amphibians (Reiter et al., 2014), testudines (Mafli et al., 2011), squamates (Plasman et al., 2015), birds (Santos et al., 2011), and mammals (Loehr et al., 2008).

The recurrent association of $\mathrm{MbC}$ with the same traits across vertebrates suggests the existence of shared developmental, genetic, and/or selective mechanisms that link the expression of $\mathrm{MbC}$ with other phenotypic aspects (Ducrest et al., 2008; Roulin and Ducrest, 2011; San-Jose and Roulin, 2018). Vertebrate MbC thus constitutes a good model system to address questions of general relevance for evolutionary biologists, particularly those regarding the evolution of the phenotype that acknowledge its multidimensional nature. The study of the proximate and ultimate causes underlying the association of $\mathrm{MbC}$ to other, disparate traits can offer insights into the molecular basis of trait correlations (Saltz et al., 2017), into how complex organisms evolve and adapt (Orr, 2000; Wagner et al., 2007; Melo et al., 2016) and how developmental and genetic constraints and trade-offs influence evolutionary trajectories, adaptation, and species differentiation (Smith et al., 1985; West-Eberhard, 2005; Mauro and Ghalambor, 2020).

With this review, our aim is to draw attention toward a new, potentially explanatory mechanism linking $\mathrm{MbC}$ with other phenotypic aspects in wild vertebrate populations. Research on domestic mammals has also encountered the recurrent association of $\mathrm{MbC}$ with different morphological and behavioral traits, a phenomenon already highlighted by Darwin and that was named the "domestication syndrome" (Wilkins et al., 2014, see also Sánchez-Villagra et al., 2015). Wilkins et al. (2014; see also Wilkins, 2019) proposed that many of the phenotypes often displayed by domestic mammals: depigmentation, floppy ears, smaller brains, reduced tooth size, higher fecundity, can be explained by deficiencies affecting the initial numbers and/or the capacity to migrate and differentiate of the cells in the neural crest, NC. Cells in the NC are the precursors of pigment cells, including melanocytes (sensu Schartl et al., 2016), as well as of different types of endocrine cells, mesenchymal cells, and neuron and glial cells (Douarin et al., 2008; Monsoro-Burq, 2015; Simões-Costa and Bronner, 2015; Rothstein et al., 2018; Etchevers et al., 2019). This shared origin increases the likelihood that genetic and environmental factors affecting the NC cells' normal development result in parallel changes in the different cell types deriving from the NC and thus, on correlated changes in different phenotypic aspects (Wilkins et al., 2014). We explore here if the ideas of Wilkins et al. (2014) can be exported outside domestic mammals and used in future studies to explore the yet unknown causes linking $\mathrm{MbC}$ and multiple phenotypic aspects in wild vertebrate populations.

\section{NEURAL CREST CELLS AND COLOR VARIATION IN WILD ANIMALS}

The neural crest, NC, is a transitory structure exclusive to the vertebrates' embryo (Donoghue et al., 2008; Shimeld and Holland, 2000). It is a cord of cells that originates from the neural plate borders and arises approximately when the neural plates join to form the embryo's neural tube (Simões-Costa and Bronner, 2015; Etchevers et al., 2019; Figures 1A,B). Cells in the NC initially lie between the dorsal ectoderm and the neural tube but, as the embryo develops, NC cells migrate to different locations, settle, and differentiate, giving rise to a remarkably wide array of cell types (Rothstein et al., 2018; Etchevers et al., 2019; Figure 1C). The specific processes underlying NC cell migration and differentiation into melanocytes and other cells types can be found in several recent reviews (Thomas and Erickson, 2008; Kelsh et al., 2009; Mills and Patterson, 2009; Etchevers et al., 2019) as well as the latest advances in deciphering the intrincated genetic network regulating each step of the NC development and differentiation (Simões-Costa and Bronner, 2015; Martik and Bronner, 2017; Hockman et al., 2019).

A first question is to understand the type of color variation that any factors affecting the NC cells might end up having in the expression of $\mathrm{MbC}$ and to what extent such NC-related variation mirrors the variation in $\mathrm{MbC}$ that we often observe and study in wild vertebrate populations. As shown by studies in the zebrafish, Danio rerio, variation in NC cells development can be expected to affect whether or not melanocytes are present in a given location of the body, and if present, in what numbers and whether they display a normal morphology (Kelsh et al., 1996). Thus, variation in NC cells development might potentially account for discrete or continuous variation in color patterns among individuals, differences in color intensity, or differences in the size of a color patch. These are all sources of variation in $\mathrm{MbC}$ that are often studied in wild populations (Luiselli et al., 1995; Horth, 2003; Bortolotti et al., 2006; Quesada and Senar, 2007; Gratten et al., 2008; Loehr et al., 2008; Kittilsen et al., 2009; Lepetz et al., 2009; Laucht et al., 2010; Roulin et al., 2010; Rosenblum et al., 2010; Mateos-Gonzalez and Senar, 2012; Chen et al., 2013; Kim et al., 2013; Saino et al., 2013; Reiter et al., 2014; Johnson and Fuller, 2015; McGlothlin et al., 2016; Tate et al., 2016; Evans and Gustafsson, 2017; Kappers et al., 2018; Romero-Diaz et al., 2019; San-Jose et al., 2019; Santostefano et al., 2019).

While variation at the level of NC development has the capacity to result in diverse and substantial changes in vertebrate coloration, evidence showing that NC cells underlie intraspecific color variation in wild species is still scarce. 
A



C

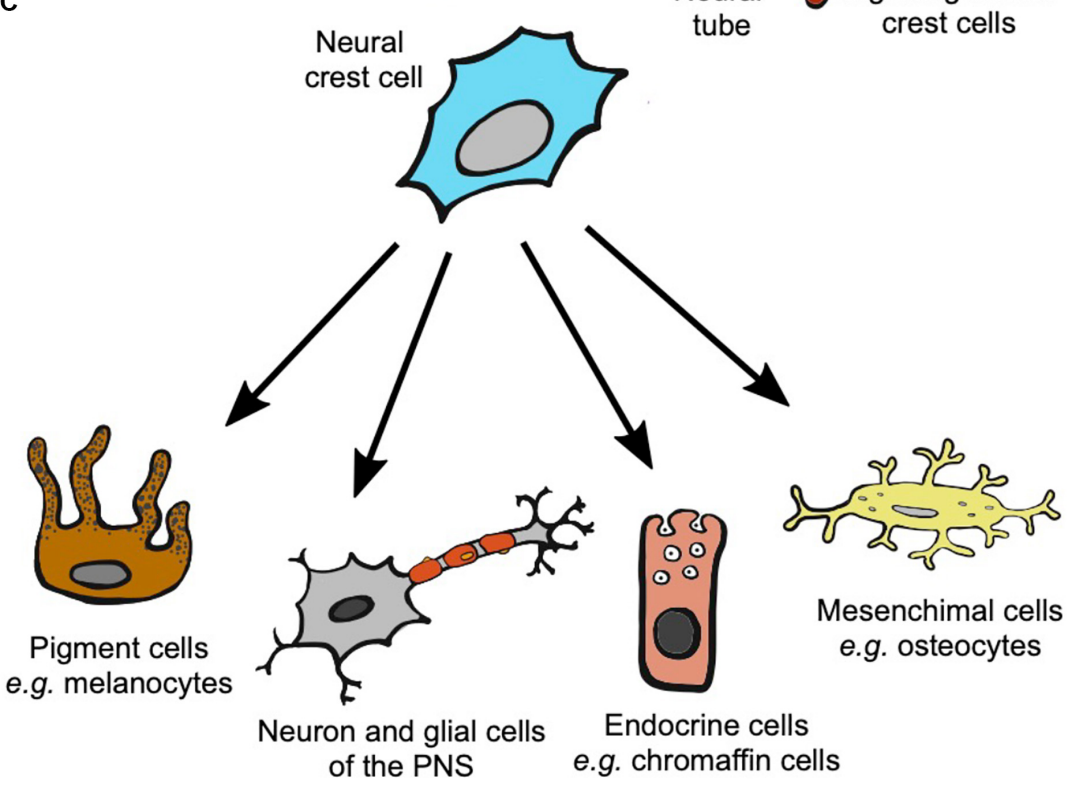

B
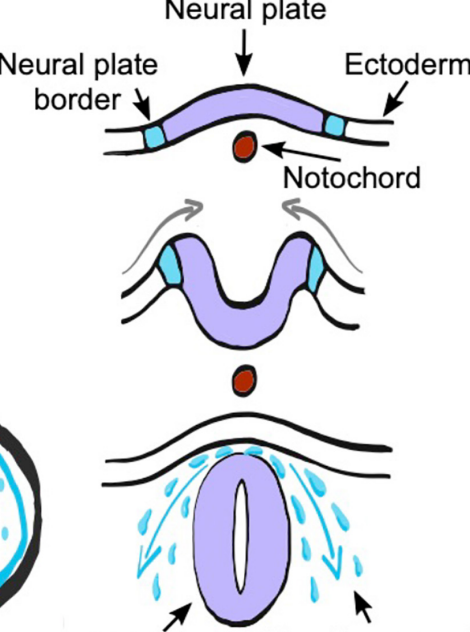

Neural OMigrating neural

FIGURE 1 | The neural crest is a transitory structure of the vertebrate embryo that initially locates on the most dorsal part of the neural tube. During development, cranial and trunk neural crest cells migrate to different parts of the embryo depending on where they originated (A). The neural crest is formed from the borders of the neural plate. The neural plate folds forming the neural tube, and neural crest cells will delaminate from the neural plate and migrate from the space between the neural tube and the ectoderm to reach different locations in the body (B). During migration and at their arrival sites, neural crest cells commit and differentiate into a wide range of cell types (C).

Variation in NC cells development can have a genetic origin (Kelsh et al., 1996; Rothstein et al., 2018; Hovland et al., 2019), although environmental factors such as temperature, maternal nutritional status and oxidative stress can also affect NC development (Finnell et al., 2004; Običan et al., 2010; Xu et al., 2013; Dreier et al., 2014). To date, genetic studies in cichlid fish species of the lake Malawi offer the best evidence of the involvement of NC cells in producing color variation in wild species, particularly through cis-regulatory mutations in Pax genes. The expression of Pax 3 and $P a x 7$ genes is required for the formation of the neural crest and, together with other genes in the Pax family, they regulate NC cells proliferation, 
suggested to underlie the formation of the characteristic egg spots or egg dummies present in the anal fins of several cichlid species (Salzburger et al., 2007; Diepeveen and Salzburger, 2011; Santos et al., 2014). The genes Ednrb1 and Tfap2a were found to be upregulated in the dark morph vs. the gold morph of the Midas cichlid, Amphilophus citrinellus (Henning et al., 2010).

Other key genes in the development of the NC cells, particularly involved in NC cells commitment and differentiation into melanocytes, have been suggested to underlie color differences between populations or species. In mouse, chicken and zebrafish, the expression of the melanocyte inducing transcription factor, MITF (mitfa in the zebrafish), is required for the production of mature melanocytes from the NC cells (Opdecamp et al., 1997; Goding, 2000; Johnson et al., 2011). In wild populations, MITF has been identified as a candidate gene underlying the characteristic color pattern of African wild dogs (Lycaon pictus) (Campana et al., 2016), and plumage color variation among populations of pied flycatchers (Ficedula hypoleuca) (Lehtonen et al., 2012). MITF might be also involved in plumage color differences between carrion and hooded crows (Corvus corone corone and C. c. cornix) (Poelstra et al., 2015). Reduced expression of the Kit ligand gene, which is involved in the survival and migration of melanoblasts (Kelsh et al., 2009), has been linked to reduced melanization of ventral body parts in some populations of threespine stickleback fish (Gasterosteus aculeatus).

\section{NON-PIGMENTARY NEURAL CREST DERIVED TISSUES: FUNCTIONS AND LINKS WITH MELANIN-BASED COLORATION}

In addition to pigment cells, the NC derivatives include different types of endocrine cells, mesenchymal cells, and neuron and glial cells (Douarin et al., 2008; Monsoro-Burq, 2015; SimõesCosta and Bronner, 2015; Rothstein et al., 2018; Etchevers et al., 2019). Here, we briefly review the main functions of these other cell types, highlighting if such functions also relate to phenotypic aspects observed in association with $\mathrm{MbC}$ in wild vertebrate populations.

Endocrine cells deriving from NC cells include adrenal medullary cells, carotid body glomus cells, and calcitoninsecreting cells of the ultimobranchial body (although the NC-cell origin of this later cell type has been questioned recently; Nilsson and Williams, 2016). Adrenal medullary cells, also known as chromaffin cells or pheochromocytes, are responsible for the synthesis and secretion of catecholamines (epinephrine, norepinephrine, and dopamine) as part of the sympatho-adrenal system (Kvetnansky et al., 2009). Catecholamines are released in response to stressors, which triggers different physiological and neuronal changes oriented to surmount the stressful conditions (e.g., increased heart rate, blood pressure, cellular metabolism, glucose levels in blood, among others). The association between $\mathrm{MbC}$ and stress response has been studied in different vertebrate species where darker individuals have been often found to be more resistant to stress (reviewed in San-Jose and Roulin, 2018). The association between $\mathrm{MbC}$ and stress is mainly considered within the context of the hypothalamus-pituitary-adrenocortical system and thus in relation to the stress hormones released by the cortex and not by the medulla of the adrenal glands (Husak and Moore, 2008; Roulin, 2016). However, the potential implication of catecholamines and the sympatho-adrenal system in explaining why $\mathrm{MbC}$ associates to stress response deserves further attention, considering also the potential interactions with the hypothalamus-pituitary-adrenocortical system (e.g., the adrenal medulla may regulate hormone secretion by the adrenal cortex and vice versa: Gallo-Payet et al., 1987; Kvetnansky et al., 2009). The fact that catecholamines can induce color changes in vertebrates (Bagnara and Matsumoto, 2007; Zhang et al., 2020) increases the interest of investigating their role in linking coloration and stress response.

Epinephrine and nor-epinephrine levels are also related with behavioral traits such as aggressiveness, boldness, and social dominance (Koolhaas et al., 1999, 2010; Chichinadze, 2004; VazSerrano et al., 2011), which are often associated with MbC (Ducrest et al., 2008; Santos et al., 2011; San-Jose and Roulin, 2018). Dopamine plays also an important role in regulating aggressive behaviors (Pavlov et al., 2012). However, dopamine does not cross the blood-brain barrier and thus the dopamine secreted by adrenal medulla is not expected to influence aggressiveness contrary to the dopamine secreted in brain tissues (Waltes et al., 2016). Peripheral dopamine (i.e., the dopamine secreted by the adrenal medulla among other tissues) is suspected to regulate metabolism, food intake, and body weight (Rubí and Maechler, 2010), which are also aspects that has been found to differ between individuals with distinct $\mathrm{MbC}$.

Calcitonin-secreting cells of the ultimobranchial body produces calcitonin, the parathyroid hormone, which has a central role in regulating calcium and phosphorus levels (Naot et al., 2018). The link between MbC and calcium levels have received some attention in birds, where increased levels of calcium in the diet enhance MbC expression (McGraw, 2003, 2007, although see Stewart and Westneat, 2010) and where melanin-pigmented feathers have been observed to accumulate more calcium (Niecke et al., 1999, 2003). One study in barn owls (Tyto alba) also showed that calcium content in bones is higher in individuals presenting more eumelanic spots in their plumage, suggesting that a link between the expression of $\mathrm{MbC}$ and calcium physiology may exist (Roulin et al., 2006). A closer look on the association between $\mathrm{MbC}$, calcitonin, and calcitonin-secreting cells may offer new insights into the links between $\mathrm{MbC}$ and calcium.

Carotid body glomus cells sense changes in oxygen tension and trigger the activation of the brainstem respiratory center to induce hyperventilation in response to hypoxemia (LopezBarneo et al., 2008). In some species, rapid change in skin coloration in response to temperature changes seems to be dependent on oxygen levels (de Velasco and Tattersall, 2008, although see also Rahn, 1956). However, we are not aware of studies directly showing that differences in MbC between individuals relate to differences in dealing with hypoxemia or hypoxia. Yet, we expect $\mathrm{MbC}$ and the response to low 
oxygen levels to be co-selected in high altitude environments (Leaché et al., 2010; Reguera et al., 2014), where darker MbC are expected to be favored at low temperatures (Delhey, 2017).

$\mathrm{NC}$ gives rise to the neurons and the glial cells of the ganglia of the peripheral nervous system (PNS) (Jessen, 2004; Bhatheja and Field, 2006). The autonomous PNS promotes the release of catecholamines by the adrenal medulla in response to stress (the sympatho-adrenal system), whose potential link to $\mathrm{MbC}$ has been discussed lines above. The autonomous PNS participate in the stress response also through the sympatho-neural system (Del Giudice et al., 2011). The sympatho-neural system is involved in regulating the immune response (Jänig, 2014), also a phenotypic aspect that has been often associated with differences in $\mathrm{MbC}$ (Côte et al., 2018). Another aspect that has been associated often with $\mathrm{MbC}$ is sexual behavior, sex steroid concentration, and fecundity (San-Jose and Roulin, 2018). The PNS regulates the production of sex hormones via sympathetic innervation of the gonads (Lara et al., 2002; Daneri et al., 2013; Bronzi et al., 2015) while the parasympathetic system has been related to sexual arousal (Giuliano et al., 2002).

Finally, NC crest cells give rise to the mesenchymal cells that further differentiate into many of the numerous distinct cells that form the organs and tissues of the head of vertebrates. Thus, NC cells differentiate into osteocytes and chondrocytes forming the facial skeleton, and the inner ear, odontoblasts producing the dentine of the teeth, and muscle and cartilage cells of the face, among others (Kaucka et al., 2016; Etchevers et al., 2019). To the best of our knowledge, head morphology has been found in association to $\mathrm{MbC}$ in at least one study. San-Jose et al. (2017) found that common lizards, Zootoca vivipara, with a more melanized ventral coloration had a larger head and a stronger bite force even when controlling for body size differences.

\section{POTENTIAL MECHANISMS OF COVARIATION}

In the previous sections, we have reviewed that (i) genetic factors linked to NC development explain color variation in some wild vertebrate species and that (ii) non-pigmentary $\mathrm{NC}$ derived tissues participate in functions previously found to be associated with $\mathrm{MbC}$ in wild species. We argue that these two general observations justify considering the shared developmental origin of melanocytes and other NC derivatives as a potential linking mechanism underlying the associations of $\mathrm{MbC}$ with other phenotypic aspects in wild vertebrates; i.e., an hypothesis to be addressed in future studies.

Genetic or environmental factors affecting the proliferation, migration, and/or initial stages of differentiation of the NC cells may impact both coloration and the functions of other NC-derived tissues in post-embryonic stages. Such mechanism of covariation was pushed forward by Wilkins et al. (2014) as an explanation for the domestication syndrome. A direct example of such a mechanism can be found on recent findings showing how mutations at the gene ADAR1 pleiotropically disrupt the development of both melanocytes and Schwann cells (the major type of glial cell of the PNS: Gacem et al., 2020). The potential for pleiotropic effects will depend on which steps of the NC development are affected by genetic or environmental factors. For instance, genetic changes as those discussed in relation to Pax3/7 genes in cichlid fishes have the capacity of affecting multiple phenotypic traits besides $\mathrm{MbC}$. The reason is that Pax3/7 genes are key for the development of the NC before NC cells start to commit and differentiate into different cell types (Martik and Bronner, 2017). Thus, changes in the functioning of Pax3/7 genes may have effects that can be inherited by different cell types. Contrarily, other genes such as MITF that may also associate to color differences in the wild have a lower potential for pleiotropic action. MITF regulates final stages of NC cells development: the differentiation of a population of NC cells into melanocytes (Martik and Bronner, 2017).

There are other mechanisms through which $\mathrm{MbC}$ and other phenotypic traits can become linked due to the functioning of other NC-derived tissues. A second mechanism of covariation might rely on the fact that multipotent NC stem cells persist in adult peripheral nerves. Such stem cells are able to leave the PNS nerves and differentiate into melanocytes (Singh et al., 2016; Dupin et al., 2018; Mehrotra et al., 2020). Thus, factors, either genetic or environmental, affecting this population of multipotent NC stem cells might have cascading effects on different tissues, linking the expression of $\mathrm{MbC}$ with other phenotypic traits. A third mechanism of covariation might be based on a direct regulation of pigmentation by the functioning of some NC-derived tissues. One example of such mechanism comes from the recent discovery of how acute stress triggers hair whitening in mammals (Zhang et al., 2020). In response to acute stress, the PNS releases norepinephrine through the sympathetic nerves that innervate melanocyte stem-cells in the hair bulb. This causes melanocyte stem-cells to rapidly proliferate and differentiate into mature melanocytes, which eventually extenuates the niche of melanocyte stem-cells and causes hair whitening. In reptiles, fishes and amphibians, catecholamines released by the adrenal medulla had been known for long to play an important role in regulating melanophore contraction and MbC (Bagnara and Matsumoto, 2007). As discussed above, this may constitute a direct link between pigmentation, stress response, and perhaps, behavior.

\section{FINAL NOTES}

Inspired by the ideas of Wilkins et al. (2014), we highlight here the potential role of the NC cells to drive associations between $\mathrm{MbC}$ and other phenotypic aspects in wild vertebrates. Such associations may result from other proposed mechanisms (reviewed in San-Jose and Roulin, 2018), among which, the pleiotropic action of the genes in the melanocortin system has received substantial attention (Ducrest et al., 2008). The genes in the melanocortin system regulate melanin synthesis as well as different aspects of behavior, morphology and physiology. As we review above, some of this aspects have also a developmental origin in the NC: stress response, metabolism, aggressiveness, sexual behavior, sex hormone levels, metabolism, 
body weight, and immune response. We think that different mechanisms such as the NC and the melanocortin system do not necessarily constitute competing hypotheses as to how MbC becomes associated with other phenotypic traits. Contrarily, they may even act in a complementary way given that they are expected to associate to the same phenotypic aspects through distinct pathways (e.g., the NC cells associate to the stress response through the sympatho-adrenal and sympathoneural systems and the melanocortin system through the hypothalamus-pituitary-adrenocortical system). Like the NC, the melanocortin system is specific of the vertebrate lineage, having its origin in early chordates (Cortés et al., 2014). We find remarkable as well as intriguing that both, the NC and the melanocortin systems constitute shared developmental and genetic mechanisms underlying the expression of similar phenotypic aspects of vertebrates. This raises the question of whether the co-expression of such traits: MbC, metabolism, stress response, sexual behavior might have had any selective advantage in the conditions in which vertebrate ancestors evolved. Or, contrarily, whether the fact that $\mathrm{MbC}$ and other phenotypic traits shared aspects of their development and regulation may be simply due to historical contingencies.

In current vertebrate populations, mechanisms such as the $\mathrm{NC}$ and the melanocortin system offer high potentiality for pleiotropic regulation of $\mathrm{MbC}$ and several other phenotypic traits. If genetic variation for such pleiotropic regulation exists selection can shape associations between $\mathrm{MbC}$ and phenotypic traits (Lande and Arnold, 1983). Acting in a correlational manner, selection on $\mathrm{MbC}$ and other traits can promote complex adaptations (Wagner and Altenberg, 1996), for instance, in ecological scenarios such as in low temperature habitats where having a darker pigmentation, a larger body size, a higher metabolism, a higher stress resistance might all be advantageous (San-Jose and Roulin, 2018). Plausible proximate mechanisms of covariation between $\mathrm{MbC}$ and other phenotypic traits also increase the likelihood for indirect selection driving trait associations as well as for the existence of developmental and genetic constraints to adaptation (Orr, 2000). By being shared across vertebrates, mechanisms of covariation such as the NC cells and the melanocortin system may help us understand why

\section{REFERENCES}

Albertson, R. C., Powder, K. E., Hu, Y., Coyle, K. P., Roberts, R. B., and Parsons, K. J. (2014). Genetic basis of continuous variation in the levels and modular inheritance of pigmentation in cichlid fishes. Mol. Ecol. 23, 5135-5150. doi: $10.1111 / \mathrm{mec} .12900$

Bagnara, J. T., and Matsumoto, J. (2007). "Comparative anatomy and physiology of pigment cells in nonmammalian tissues," in The Pigmentary System: Physiology and Pathophysiology, eds J. J. Nordlund, R. E. Boissy, V. J. Hearing, R. A. King, W. S. Oetting, and J.-P. Ortonne (Oxford: Blackwell Publishing), 11-59. doi: 10.1002/9780470987100.ch2

Bhatheja, K., and Field, J. (2006). Schwann cells: origins and role in axonal maintenance and regeneration. Int. J. Biochem. Cell Biol. 38, 1995-1999. doi: 10.1016/j.biocel.2006.05.007

Bortolotti, G. R., Blas, J., Negro, J. J., and Tella, J. L. (2006). A complex plumage pattern as an honest social signal. Anim. Behav. 72, 423-430. doi: 10.1016/j. anbehav.2006.01.016 and how similar association between $\mathrm{MbC}$ and other phenotypic traits can be recurrently found within (e.g., Santos et al., 2011) and across distinct vertebrate taxa (Eliason and Clarke, 2018).

Research on the potential role of the NC cells in linking different phenotypic aspects will thus offer insights into both the proximate and ultimate causes of associations between $\mathrm{MbC}$ and distinct phenotypic traits. Taxa such cichlid fish seem good model species to test for correlated changes between $\mathrm{MbC}$ and other traits with developmental roots in the $\mathrm{NC}$ and to investigate how selection might be jointly acting on $\mathrm{MbC}$ and associated traits. Cichlid fish are also a good system to investigate how NC cells and the melanocortin system interact and affect different traits (Dijkstra et al., 2017). The zebra fish, Danio rerio, is also a promising model system in controlled laboratory conditions, taking advantage of the different existing color mutants for NCrelated genes (Singh and Nüsslein-Volhard, 2015). We expect that research on how the $\mathrm{NC}$ origin of $\mathrm{MbC}$ might result in associations of coloration with ecologically relevant traits will bring together developmental biology and evolutionary ecology to better understand the evolution of animal coloration.

\section{AUTHOR CONTRIBUTIONS}

LS-J and AR conducted the review and synthesis of the literature and wrote the manuscript. Both authors contributed to the article and approved the submitted version.

\section{FUNDING}

We acknowledge the Swiss National Science Foundation for funding (ref: 173178 to AR).

\section{ACKNOWLEDGMENTS}

We are grateful to Jessica Delhaye, Adam S. Wilkins, and two reviewers for their constructive comments on earlier versions of our manuscript.

Brenner, M., and Hearing, V. J. (2008). The protective role of melanin against UV damage in human skin. Photochem. Photobiol. 84, 539-549. doi: 10.1111/j.17511097.2007.00226.x

Bronzi, C. D., Vega Orozco, A. S., Rodriguez, D., Rastrilla, A. M., Sosa, Z. Y., and Casais, M. (2015). Noradrenaline modulates the presence of gonadotropinreleasing hormone in ovary. The importance of its interrelation on the ovarian steroidogenesis and apoptosis on dioestrus II in rat. J. Steroid Biochem. Mol. Biol. 154, 39-46. doi: 10.1016/j.jsbmb.2015.06.005

Campana, M. G., Parker, L. D., Hawkins, M. T. R., Young, H. S., Helgen, K. M., Szykman Gunther, M., et al. (2016). Genome sequence, population history, and pelage genetics of the endangered African wild dog (Lycaon pictus). BMC Genomics 17:1013. doi: 10.1186/s12864016-3368-9

Chen, I.-P., Symonds, M. R. E., Melville, J., and Stuart-Fox, D. (2013). Factors shaping the evolution of colour patterns in Australian agamid lizards (Agamidae): a comparative study: evolution of Colour Patterns. Biol. J. Linn. Soc. Lond. 109, 101-112. doi: 10.1111/bij.12030 
Chichinadze, K. N. (2004). Motor and neurochemical correlates of aggressive behavior in male mice. Neurophysiology 36, 262-269. doi: 10.1007/s11062-0040005-z

Clusella-Trullas, S., Terblanche, J. S., Blackburn, T. M., and Chown, S. L. (2008). Testing the thermal melanism hypothesis: a macrophysiological approach. Funct. Ecol. 22, 232-238. doi: 10.1111/j.1365-2435.2007.01377.x

Cortés, R., Navarro, S., Agulleiro, M. J., Guillot, R., García-Herranz, V., Sánchez, E., et al. (2014). Evolution of the melanocortin system. Gen. Comp. Endocrinol. 209, 3-10. doi: 10.1016/j.ygcen.2014.04.005

Côte, J., Boniface, A., Blanchet, S., Hendry, A. P., Gasparini, J., and Jacquin, L. (2018). Melanin-based coloration and host-parasite interactions under global change. Proc. R. Soc. B Biol. Sci. 285:20180285. doi: 10.1098/rspb.2018. 0285

Daneri, C., Orozco, A. V., Bronzi, D., Mohn, C., Rastrilla, A. M., and Sosa, Z. Y. (2013). Involvement of the ganglion cholinergic receptors in gonadotropinreleasing hormone, catecholamines, and progesterone release in the rat ovary. Fertil. Steril. 99, 2062-2070. doi: 10.1016/j.fertnstert.2013.02.037

de Velasco, J. B., and Tattersall, G. J. (2008). The influence of hypoxia on the thermal sensitivity of skin colouration in the bearded dragon, Pogona vitticeps. J. Comp. Physiol. B 178, 867-875. doi: 10.1007/s00360-008-0274-8

Del Giudice, M., Ellis, B. J., and Shirtcliff, E. A. (2011). The adaptive calibration model of stress responsivity. Neurosci. Biobehav. Rev. 35, 1562-1592. doi: 10. 1016/j.neubiorev.2010.11.007

Delhey, K. (2017). Gloger's rule. Curr. Biol. 27, R689-R691. doi: 10.1016/j.cub.2017. 04.031

Diepeveen, E. T., and Salzburger, W. (2011). Molecular characterization of two endothelin pathways in east african cichlid fishes. J. Mol. Evol. 73, 355-368. doi: 10.1007/s00239-012-9483-6

Dijkstra, P. D., Maguire, S. M., Harris, R. M., Rodriguez, A. A., DeAngelis, R. S., Flores, S. A., et al. (2017). The melanocortin system regulates body pigmentation and social behaviour in a colour polymorphic cichlid fish. Proc. R. Soc. B Biol. Sci. 284:20162838. doi: 10.1098/rspb.2016.2838

Donoghue, P. C. J., Graham, A., and Kelsh, R. N. (2008). The origin and evolution of the neural crest. Bioessays 30, 530-541. doi: 10.1002/bies.20767

Douarin, N. M. L., Calloni, G. W., and Dupin, E. (2008). The stem cells of the neural crest. Cell Cycle 7, 1013-1019. doi: 10.4161/cc.7.8.5641

Dreier, J. W., Andersen, A.-M. N., and Berg-Beckhoff, G. (2014). Systematic review and meta-analyses: fever in pregnancy and health impacts in the offspring. Pediatrics 133, e674-e688. doi: 10.1542/peds.2013-3205

Ducrest, A.-L., Keller, L., and Roulin, A. (2008). Pleiotropy in the melanocortin system, coloration and behavioural syndromes. Trends Ecol. Evol. 23, 502-510. doi: 10.1016/j.tree.2008.06.001

Dupin, E., Calloni, G. W., Coelho-Aguiar, J. M., and Le Douarin, N. M. (2018). The issue of the multipotency of the neural crest cells. Dev. Biol. 444, S47-S59. doi: 10.1016/j.ydbio.2018.03.024

Eliason, C. M., and Clarke, J. A. (2018). Metabolic physiology explains macroevolutionary trends in the melanic colour system across amniotes. Proc. R. Soc. B Biol. Sci. 285:20182014. doi: 10.1098/rspb.2018.2014

Etchevers, H. C., Dupin, E., and Douarin, N. M. L. (2019). The diverse neural crest: from embryology to human pathology. Development 146:dev169821. doi: 10.1242/dev.169821

Evans, S. R., and Gustafsson, L. (2017). Climate change upends selection on ornamentation in a wild bird. Nat. Ecol. Evol. 1:39. doi: 10.1038/s41559-0160039

Finnell, R. H., Shaw, G. M., Lammer, E. J., Brandl, K. L., Carmichael, S. L., and Rosenquist, T. H. (2004). Gene-nutrient interactions: importance of folates and retinoids during early embryogenesis. Toxicol. Appl. Pharmacol. 198, 75-85. doi: 10.1016/j.taap.2003.09.031

Gacem, N., Kavo, A., Zerad, L., Richard, L., Mathis, S., Kapur, R. P., et al. (2020). ADAR1 mediated regulation of neural crest derived melanocytes and Schwann cell development. Nat. Commun. 11:198. doi: 10.1038/s41467-019-14 090-5

Gallo-Payet, N., Pothier, P., and Isler, H. (1987). On the presence of chromaffin cells in the adrenal cortex: their possible role in adrenocortical function. Biochem. Cell Biol. 65, 588-592. doi: 10.1139/o87-076

Giuliano, F., Rampin, O., and Allard, J. (2002). Neurophysiology and pharmacology of female genital sexual response. J. Sex Marital Ther. 28, 101-121. doi: 10.1080/00926230252851230
Goding, C. R. (2000). Mitf from neural crest to melanoma: signal transduction and transcription in the melanocyte lineage. Genes Dev. 14, 1712-1728. doi: 10.1101/gad.14.14.1712

Gratten, J., Wilson, A. J., McRae, A. F., Beraldi, D., Visscher, P. M., Pemberton, J. M., et al. (2008). A localized negative genetic correlation constrains microevolution of coat color in wild sheep. Science 319, 318-320. doi: 10.1126/ science. 1151182

Henning, F., Renz, A. J., Fukamachi, S., and Meyer, A. (2010). Genetic, comparative genomic, and expression analyses of the $M c 1 r$ locus in the polychromatic midas cichlid fish (Teleostei, Cichlidae Amphilophus sp.) Species Group. J. Mol. Evol. 70, 405-412. doi: 10.1007/s00239-010-9340-4

Hockman, D., Chong-Morrison, V., Green, S. A., Gavriouchkina, D., CandidoFerreira, I., Ling, I. T. C., et al. (2019). A genome-wide assessment of the ancestral neural crest gene regulatory network. Nat. Commun. 10:4689. doi: 10.1038/s41467-019-12687-4

Horth, L. (2003). Melanic body colour and aggressive mating behaviour are correlated traits in male mosquitofish (Gambusia holbrooki). Proc. Biol. Sci. R. Soc. 270, 1033-1040. doi: 10.1098/rspb.2003.2348

Hovland, A. S., Rothstein, M., and Simoes-Costa, M. (2019). Network architecture and regulatory logic in neural crest development. Wiley Interdiscip. Rev. Syst. Biol. Med. 12:e1468. doi: 10.1002/wsbm.1468

Husak, J. F., and Moore, I. T. (2008). Stress hormones and mate choice. Trends Ecol. Evol. 23, 532-534. doi: 10.1016/j.tree.2008.06.007

Jänig, W. (2014). Sympathetic nervous system and inflammation: a conceptual view. Auton. Neurosci. 182, 4-14. doi: 10.1016/j.autneu.2014.01.004

Jessen, K. R. (2004). Glial cells. Int. J. Biochem. Cell Biol. 36, 1861-1867. doi: 10.1016/j.biocel.2004.02.023

Johnson, A. M., and Fuller, R. C. (2015). The meaning of melanin, carotenoid, and pterin pigments in the bluefin killifish, Lucania goodei. Behav. Ecol. 26, 158-167. doi: 10.1093/beheco/aru164

Johnson, S. L., Nguyen, A. N., and Lister, J. A. (2011). mitfa is required at multiple stages of melanocyte differentiation but not to establish the melanocyte stem cell. Dev. Biol. 350, 405-413. doi: 10.1016/j.ydbio.2010.12.004

Kappers, E. F., de Vries, C., Alberda, A., Forstmeier, W., Both, C., and Kempenaers, B. (2018). Inheritance patterns of plumage coloration in common buzzards Buteo buteo do not support a one-locus two-allele model. Biol. Lett. 14:20180007. doi: 10.1098/rsbl.2018.0007

Kaucka, M., Ivashkin, E., Gyllborg, D., Zikmund, T., Tesarova, M., Kaiser, J., et al. (2016). Analysis of neural crest-derived clones reveals novel aspects of facial development. Sci. Adv. 2:e1600060. doi: 10.1126/sciadv.1600060

Kelsh, R. N., Brand, M., Jiang, Y. J., Heisenberg, C. P., Lin, S., Haffter, P., et al. (1996). Zebrafish pigmentation mutations and the processes of neural crest development. Development 123, 369-389.

Kelsh, R. N., Harris, M. L., Colanesi, S., and Erickson, C. A. (2009). Stripes and belly-spots - a review of pigment cell morphogenesis in vertebrates. Semin. Cell Dev. Biol. 20, 90-104. doi: 10.1016/j.semcdb.2008.10.001

Kim, S.-Y., Fargallo, J. A., Vergara, P., and Martinez-Padilla, J. (2013). Multivariate heredity of melanin-based coloration, body mass and immunity. Heredity 111, 139-146. doi: 10.1038/hdy.2013.29

Kittilsen, S., Schjolden, J., Beitnes-Johansen, I., Shaw, J. C., Pottinger, T. G., Sørensen, C., et al. (2009). Melanin-based skin spots reflect stress responsiveness in salmonid fish. Horm. Behav. 56, 292-298. doi: 10.1016/j.yhbeh.2009.06.006

Koolhaas, J. M., de Boer, S. F., Coppens, C. M., and Buwalda, B. (2010). Neuroendocrinology of coping styles: towards understanding the biology of individual variation. Front. Neuroendocrinol. 31:307-321. doi: 10.1016/j.yfrne. 2010.04.001

Koolhaas, J. M., Korte, S. M., De Boer, S. F., Van Der Vegt, B. J., Van Reenen, C. G., Hopster, H., et al. (1999). Coping styles in animals: current status in behavior and stress-physiology. Neurosci. Biobehav. Rev. 23, 925-935. doi: 10. 1016/S0149-7634(99)00026-3

Kvetnansky, R., Sabban, E. L., and Palkovits, M. (2009). Catecholaminergic systems in stress: structural and molecular genetic approaches. Physiol. Rev. 89, 535-606. doi: 10.1152/physrev.00042.2006

Lande, R., and Arnold, S. J. (1983). The measurement of selection on correlated characters. Evolution 37, 1210-1226. doi: 10.1111/j.1558-5646.1983.tb00236.x

Lara, H. E., Dorfman, M., Venegas, M., Luza, S. M., Luna, S. L., Mayerhofer, A., et al. (2002). Changes in sympathetic nerve activity of the mammalian ovary 
during a normal estrous cycle and in polycystic ovary syndrome: studies on norepinephrine release. Microsc. Res. Tech. 59, 495-502. doi: 10.1002/jemt. 10229

Laucht, S., Kempenaers, B., and Dale, J. (2010). Bill color, not badge size, indicates testosterone-related information in house sparrows. Behav. Ecol. Sociobiol. 64, 1461-1471. doi: 10.1007/s00265-010-0961-9

Leaché, A. D., Helmer, D.-S., and Moritz, C. (2010). Phenotypic evolution in highelevation populations of western fence lizards (Sceloporus occidentalis) in the Sierra Nevada Mountains. Biol. J. Linn. Soc. 100, 630-641. doi: 10.1111/j.10958312.2010.01462.x

Lehtonen, P. K., Laaksonen, T., Artemyev, A. V., Belskii, E., Berg, P. R., Both, C., et al. (2012). Candidate genes for colour and vision exhibit signals of selection across the pied flycatcher (Ficedula hypoleuca) breeding range. Heredity 108, 431-440. doi: 10.1038/hdy.2011.93

Lepetz, V., Massot, M., Chaine, A. S., and Clobert, J. (2009). Climate warming and the evolution of morphotypes in a reptile. Glob. Change Biol. 15, 454-466. doi: 10.1080/00031305.1989.10475662

Loehr, J., Carey, J., Ylönen, H., and Suhonen, J. (2008). Coat darkness is associated with social dominance and mating behaviour in a mountain sheep hybrid lineage. Anim. Behav. 76, 1545-1553. doi: 10.1016/j.anbehav.2008. 07.012

Lopez-Barneo, J., Ortega-Saenz, P., Pardal, R., Pascual, A., and Piruat, J. I. (2008). Carotid body oxygen sensing. Eur. Respir. J. 32, 1386-1398. doi: 10.1183/ 09031936.00056408

Luiselli, L., Monney, J.-C., and Capula, M. (1995). Correlates of melanism in a population of adders (Vipera berus) from the Swiss Alps and comparisons with other alpine populations. Amphib. Reptil. 16, 323-330. doi: 10.1163/ 156853895X00406

Mafli, A., Wakamatsu, K., and Roulin, A. (2011). Melanin-based coloration predicts aggressiveness and boldness in captive eastern Hermann's tortoises. Anim. Behav. 81, 859-863. doi: 10.1016/j.anbehav.2011.01.025

Martik, M. L., and Bronner, M. E. (2017). Regulatory logic underlying diversification of the neural crest. Trends Genet. 33, 715-727. doi: 10.1016/j. tig.2017.07.015

Mateos-Gonzalez, F., and Senar, J. C. (2012). Melanin-based trait predicts individual exploratory behaviour in siskins, Carduelis spinus. Anim. Behav. 83, 229-232. doi: 10.1016/j.anbehav.2011.10.030

Mauro, A. A., and Ghalambor, C. K. (2020). Trade-offs, pleiotropy, and shared molecular pathways: a unified view of constraints on adaptation. Integr. Comp. Biol. doi: 10.1093/icb/icaa056

McGlothlin, J. W., Parker, P. G., Nolan, V., and Ketterson, E. D. (2016). Correlational selection leads to genetic integration of body size and an attractive plumage trait in dark-eyed juncos. Evolution 59, 658-671. doi: 10.1111/j.00143820.2005.tb01024.x

McGraw, K. (2003). Melanins, metals, and mate quality. Oikos 102, 402-406. doi: 10.1034/j.1600-0579.2003.12513.x

McGraw, K. J. (2007). Dietary mineral content influences the expression of melanin-based ornamental coloration. Behav. Ecol. 18, 137-142. doi: 10.1093/ beheco/arl059

Mehrotra, P., Tseropoulos, G., Bronner, M. E., and Andreadis, S. T. (2020). Adult tissue-derived neural crest-like stem cells: sources, regulatory networks, and translational potential. Stem Cells Transl. Med. 9, 328-341. doi: 10.1002/sctm. 19-0173

Melo, D., Porto, A., Cheverud, J. M., and Marroig, G. (2016). Modularity: genes, development, and evolution. Annu. Rev. Ecol. Evol. Syst. 47, 463-486. doi: 10.1146/annurev-ecolsys-121415-032409

Mills, M. G., and Patterson, L. B. (2009). Not just black and white: pigment pattern development and evolution in vertebrates. Semin. Cell Dev. Biol. 20, 72-81. doi: $10.1016 /$ j.semcdb.2008.11.012

Minchin, J. E. N., and Hughes, S. M. (2008). Sequential actions of Pax3 and Pax7 drive xanthophore development in zebrafish neural crest. Dev. Biol. 317, 508-522. doi: 10.1016/j.ydbio.2008.02.058

Monsoro-Burq, A. H. (2015). PAX transcription factors in neural crest development. Semin. Cell Dev. Biol. 44, 87-96. doi: 10.1016/j.semcdb.2015. 09.015

Naot, D., Musson, D. S., and Cornish, J. (2018). The activity of peptides of the calcitonin family in bone. Physiol. Rev. 99, 781-805. doi: 10.1152/physrev. 00066.2017
Niecke, M., Heid, M., and Krüger, A. (1999). Correlations between melanin pigmentation and element concentration in feathers of White-tailed Eagles (Haliaeetus albicilla). J. Ornithol. 140, 355-362. doi: 10.1007/BF0165 1032

Niecke, M., Rothlaender, S., and Roulin, A. (2003). Why do melanin ornaments signal individual quality? Insights from metal element analysis of barn owl feathers. Oecologia 137, 153-158. doi: 10.1007/s00442-003-1307-3

Nilsson, M., and Williams, D. (2016). On the origin of cells and derivation of thyroid cancer: C cell story revisited. ETJ 5, 79-93. doi: 10.1159/00044 7333

Običan, S. G., Finnell, R. H., Mills, J. L., Shaw, G. M., and Scialli, A. R. (2010). Folic acid in early pregnancy: a public health success story. FASEB J. 24, 4167-4174. doi: 10.1096/fj.10-165084

Opdecamp, K., Nakayama, A., Nguyen, M. T., Hodgkinson, C. A., Pavan, W. J., and Arnheiter, H. (1997). Melanocyte development in vivo and in neural crest cell cultures: crucial dependence on the Mitf basic-helix-loop-helix-zipper transcription factor. Development 124, 2377-2386.

Orr, H. A. (2000). Adaptation and the cost of complexity. Evolution 54, 13-20. doi: 10.1111/j.0014-3820.2000.tb00002.x

Pavlov, K. A., Chistiakov, D. A., and Chekhonin, V. P. (2012). Genetic determinants of aggression and impulsivity in humans. J. Appl. Genet. 53, 61-82. doi: 10.1007/ s13353-011-0069-6

Plasman, M., Reynoso, V. H., Nicolás, L., and Torres, R. (2015). Multiple colour traits signal performance and immune response in the Dickerson's collared lizard Crotaphytus dickersonae. Behav. Ecol. Sociobiol. 765-775. doi: 10.1007/ s00265-015-1892-2

Poelstra, J. W., Vijay, N., Hoeppner, M. P., and Wolf, J. B. W. (2015). Transcriptomics of colour patterning and coloration shifts in crows. Mol. Ecol. 24, 4617-4628. doi: 10.1111/mec.13353

Quesada, J., and Senar, J. C. (2007). The role of melanin- and carotenoid-based plumage coloration in nest defence in the Great Tit. Ethology 113, 640-647. doi: 10.1111/j.1439-0310.2007.01364.x

Rahn, H. (1956). The relationship between hypoxia, temperature, adrenalin release and melanophore expansion in the lizard, Anolis carolinensis. Copeia 1956, 214-217. doi: 10.2307/1440273

Reguera, S., Zamora-Camacho, F. J., and Moreno-Rueda, G. (2014). The lizard Psammodromus algirus (Squamata: Lacertidae) is darker at high altitudes. Biol. J. Linn. Soc. 112, 132-141. doi: 10.1111/bij.12250

Reiter, M., Anthony, C., and Hickerson, C.-A. M. (2014). Territorial behavior and ecological divergence in a polymorphic salamander. Copeia 2014, 481-488. doi: $10.1643 /$ ce-13-154

Roberts, R. B., Moore, E. C., and Kocher, T. D. (2017). An allelic series at pax7a is associated with colour polymorphism diversity in Lake Malawi cichlid fish. Mol. Ecol. 26, 2625-2639. doi: 10.1111/mec.13975

Roberts, R. B., Ser, J. R., and Kocher, T. D. (2009). Sexual conflict resolved by invasion of a novel sex determiner in Lake Malawi cichlid fishes. Science 326, 998-1001. doi: 10.1126/science.1174705

Romero-Diaz, C., Rivera, J. A., Ossip-Drahos, A. G., Zúñiga-Vega, J. J., VitalGarcía, C., Hews, D. K., et al. (2019). Losing the trait without losing the signal: evolutionary shifts in communicative colour signalling. J. Evol. Biol. 32, 320-330. doi: 10.1111/jeb.13416

Rosenblum, E. B., Römpler, H., Schöneberg, T., and Hoekstra, H. E. (2010). Molecular and functional basis of phenotypic convergence in white lizards at White Sands. Proc. Natl. Acad. Sci. U.S.A. 107, 2113-2117. doi: 10.1073/pnas. 0911042107

Rothstein, M., Bhattacharya, D., and Simoes-Costa, M. (2018). The molecular basis of neural crest axial identity. Dev. Biol. 444, S170-S180. doi: 10.1016/j.ydbio. 2018.07.026

Roulin, A. (2016). Condition-dependence, pleiotropy and the handicap principle of sexual selection in melanin-based colouration. Biol. Rev. 91, 328-348. doi: $10.1111 /$ brv.12171

Roulin, A., Altwegg, R., Jensen, H., Steinsland, I., and Schaub, M. (2010). Sexdependent selection on an autosomal melanic female ornament promotes the evolution of sex ratio bias. Ecol. Lett. 13, 616-626. doi: 10.1111/j.1461-0248. 2010.01459.x

Roulin, A., Dauwe, T., Blust, R., Eens, M., and Beaud, M. (2006). A link between eumelanism and calcium physiology in the barn owl. Naturwissenschaften 93, 426-430. doi: 10.1007/s00114-006-0128-8 
Roulin, A., and Ducrest, A.-L. (2011). Association between melanism, physiology and behaviour: a role for the melanocortin system. Eur. J. Pharmacol. 660, 226-233. doi: 10.1016/j.ejphar.2011.01.036

Roy, A., Pittman, M., Saitta, E. T., Kaye, T. G., and Xu, X. (2020). Recent advances in amniote palaeocolour reconstruction and a framework for future research. Biol. Rev. 95, 22-50. doi: 10.1111/brv.12552

Rubí, B., and Maechler, P. (2010). Minireview: new roles for peripheral dopamine on metabolic control and tumor growth: let's seek the balance. Endocrinology 151, 5570-5581. doi: 10.1210/en.2010-0745

Saino, N., Canova, L., Costanzo, A., Rubolini, D., Roulin, A., and Møller, A. P. (2013). Immune and stress responses Covary with melanin-based coloration in the barn swallow. Evol. Biol. 40, 521-531. doi: 10.1007/s11692-013-9228-5

Saltz, J. B., Hessel, F. C., and Kelly, M. W. (2017). Trait correlations in the genomics era. Trends Ecol. Evol. 32, 279-290. doi: 10.1016/j.tree.2016.12.008

Salzburger, W., Braasch, I., and Meyer, A. (2007). Adaptive sequence evolution in a color gene involved in the formation of the characteristic egg-dummies of male haplochromine cichlid fishes. BMC Biol. 5:51. doi: 10.1186/1741-7007-5-51

Sánchez-Villagra, M. R., Geiger, M., and Schneider, R. A. (2015). The taming of the neural crest: a developmental perspective on the origins of morphological covariation in domesticated mammals. R. Soc. Open Sci. 3:160107. doi: 10.1098/ rsos. 160107

San-Jose, L. M., Huyghe, K., Schuerch, J., and Fitze, P. S. (2017). More melanized males bite stronger but run slower: potential performance trade-offs related to melanin-based coloration. Biol. J. Linn. Soc. 122, 184-196. doi: 10.1093/ biolinnean/blx045

San-Jose, L. M., and Roulin, A. (2018). Toward understanding the repeated occurrence of associations between melanin-based coloration and multiple phenotypes. Am. Nat. 192, 111-130. doi: 10.1086/698010

San-Jose, L. M., Séchaud, R., Schalcher, K., Judes, C., Questiaux, A., Oliveira-Xavier, A., et al. (2019). Differential fitness effects of moonlight on plumage colour morphs in barn owls. Nat. Ecol. Evol. 3, 1331-1340. doi: 10.1038/s41559-01909672

Santos, E. S. A., Scheck, D., and Nakagawa, S. (2011). Dominance and plumage traits: meta-analysis and metaregression analysis. Anim. Behav. 82, 3-19. doi: 10.1016/j.anbehav.2011.03.022

Santos, M. E., Braasch, I., Boileau, N., Meyer, B. S., Sauteur, L., Böhne, A., et al. (2014). The evolution of cichlid fish egg-spots is linked with a cis-regulatory change. Nat. Commun. 5:5149. doi: 10.1038/ncomms6149

Santostefano, F., Fanson, K. V., Endler, J. A., and Biro, P. A. (2019). Behavioral, energetic, and color trait integration in male guppies: testing the melanocortin hypothesis. Behav. Ecol. 30, 1539-1547. doi: 10.1093/beheco/arz109

Schartl, M., Larue, L., Goda, M., Bosenberg, M. W., Hashimoto, H., and Kelsh, R. N. (2016). What is a vertebrate pigment cell? Pigment Cell Melanoma Res. 29, 8-14. doi: $10.1111 / \mathrm{pcmr} .12409$

Schweitzer, C., Motreuil, S., and Dechaume-Moncharmont, F.-X. (2015). Coloration reflects behavioural types in the convict cichlid, Amatitlania siquia. Anim. Behav. 105, 201-209. doi: 10.1016/j.anbehav.2015.04.024

Shimeld, S. M., and Holland, P. W. H. (2000). Vertebrate innovations. Proc. Natl. Acad. Sci. U.S.A. 97, 4449-4452. doi: 10.1073/pnas.97.9.4449

Simões-Costa, M., and Bronner, M. E. (2015). Establishing neural crest identity: a gene regulatory recipe. Development 142, 242-257. doi: 10.1242/dev.105445

Singaravelan, N., Grishkan, I., Beharav, A., Wakamatsu, K., Ito, S., and Nevo, E. (2008). Adaptive melanin response of the soil fungus Aspergillus niger to UV radiation stress at "Evolution Canyon", Mount Carmel, Israel. PLoS One 3:e2993. doi: 10.1371/journal.pone.0002993

Singh, A. P., Dinwiddie, A., Mahalwar, P., Schach, U., Linker, C., Irion, U., et al. (2016). Pigment cell progenitors in Zebrafish Remain multipotent through metamorphosis. Dev. Cell 38, 316-330. doi: 10.1016/j.devcel.2016.06.020

Singh, A. P., and Nüsslein-Volhard, C. (2015). Zebrafish stripes as a model for vertebrate colour pattern formation. Curr. Biol. 25, R81-R92. doi: 10.1016/j.cub. 2014.11.013
Smith, J. M., Burian, R., Kauffman, S., Alberch, P., Campbell, J., Goodwin, B., et al. (1985). Developmental constraints and evolution: a perspective from the mountain lake conference on development and evolution. Q. Rev. Biol. 60, 265-287. doi: 10.1086/414425

Stewart, I. R. K., and Westneat, D. F. (2010). Dietary calcium negatively affects the size of a status signal in juvenile male house sparrows (Passer domesticus)El Calcio de la Dieta Afecta Negativamente el Tamaño de una Señal de Estatus en los Machos Jóvenes de Passer domesticus. Auk 127, 549-557. doi: 10.1525/auk. 2010.10048

Stoddard, M. C., and Prum, R. O. (2011). How colorful are birds? Evolution of the avian plumage color gamut. Behav. Ecol. 22, 1042-1052. doi: 10.1093/beheco/ $\operatorname{arr} 088$

Tate, G. J., Bishop, J. M., and Amar, A. (2016). Differential foraging success across a light level spectrum explains the maintenance and spatial structure of colour morphs in a polymorphic bird. Ecol. Lett. 19, 679-686. doi: 10.1111/ele. 12606

Thomas, A. J., and Erickson, C. A. (2008). The making of a melanocyte: the specification of melanoblasts from the neural crest. Pigment Cell Melanoma Res. 21, 598-610. doi: 10.1111/j.1755-148X.2008.00506.x

Vaz-Serrano, J., Ruiz-Gomez, M. L., Gjøen, H. M., Skov, P. V., Huntingford, F. A., Øverli, Ø., et al. (2011). Consistent boldness behaviour in early emerging fry of domesticated Atlantic salmon (Salmo salar): decoupling of behavioural and physiological traits of the proactive stress coping style. Physiol. Behav. 103, 359-364. doi: 10.1016/j.physbeh.2011.02.025

Wagner, G. P., and Altenberg, L. (1996). Complex adaptations and the evolution of evolvability. Evolution 50, 967-976. doi: 10.2307/2410639

Wagner, G. P., Pavlicev, M., and Cheverud, J. M. (2007). The road to modularity. Nat. Rev. Genet. 8, 921-931. doi: 10.1038/nrg2267

Waltes, R., Chiocchetti, A. G., and Freitag, C. M. (2016). The neurobiological basis of human aggression: a review on genetic and epigenetic mechanisms. Am.J. Med. Genet. Part B Neuropsychiatr. Genet. 171, 650-675. doi: 10.1002/ajmg.b. 32388

West-Eberhard, M. J. (2005). Developmental plasticity and the origin of species differences. Proc. Natl. Acad. Sci. U.S.A. 102, 6543-6549. doi: 10.1073/pnas. 0501844102

Wilkins, A. S. (2019). A striking example of developmental bias in an evolutionary process: the "domestication syndrome". Evol. Dev. 22, 143-153. doi: 10.1111/ ede. 12319

Wilkins, A. S., Wrangham, R. W., and Tecumseh Fitch, W. (2014). The "domestication syndrome" in mammals: a unified explanation based on neural crest cell behavior and genetics. Genetics 197, 795-808. doi: 10.1534/genetics. 114.165423

Xu, C., Li, X., Wang, F., Weng, H., and Yang, P. (2013). Trehalose prevents neural tube defects by correcting maternal diabetes-suppressed autophagy and neurogenesis. Am. J. Physiol. Endocrinol. Metab. 305, E667-E678. doi: 10.1152/ ajpendo.00185.2013

Zhang, B., Ma, S., Rachmin, I., He, M., Baral, P., Choi, S., et al. (2020). Hyperactivation of sympathetic nerves drives depletion of melanocyte stem cells. Nature 577, 676-681. doi: 10.1038/s41586-020-1935-3

Conflict of Interest: The authors declare that the research was conducted in the absence of any commercial or financial relationships that could be construed as a potential conflict of interest.

Copyright (C) 2020 San-Jose and Roulin. This is an open-access article distributed under the terms of the Creative Commons Attribution License (CC BY). The use, distribution or reproduction in other forums is permitted, provided the original author(s) and the copyright owner(s) are credited and that the original publication in this journal is cited, in accordance with accepted academic practice. No use, distribution or reproduction is permitted which does not comply with these terms. 